\title{
PENGARUH PERILAKU KONSUMSI MAKANAN INSTAN YANG MENGADUNG NATRIUM TERHADAP TEKANAN DARAH PADA PENDERITA HIPERTENSI
}

\author{
Alfridsyah ${ }^{1}$, Ampera Miko ${ }^{2}$, Suci Naziatul Firda ${ }^{3}$ \\ 1,2,3 Jurusan Gizi, Politeknik Kesehatan Kemenkes Aceh, Jl. Soekarno Hatta, Kampus Terpadu Poltekkes \\ Kemenkes RI Aceh Lampeneurut, Aceh Besar. Telp.065146126. email: alfridsyah.ed@gmail.com
}

\begin{abstract}
ABSTRAK
Penyebab utama tingginya kasus meninggal akibat tekanan darah tinggi adalah mengkonsumsi makanan mengandung banyak natrium sehingga tubuh kita menampung darah yang berlebihan yang di butuhkan dan retensi cairan. Masyarakat Indonesia, sangat konsumtif dan selalu menginginkan praktis, tetapi tidak pernah mau peduli kesehatan badannya. Penelitian bersifat diskriptifanalitik dengan menggunakan desain case control, pengambilan sampel secara random sampling yaitu sebanyak 35 kasus dan 35 orang kontrol. Data yang diambil meliputi data karakteristik sampel, konsumsi makanan instan serta tekanan darah pada sampel dengan pengukur tekanan darah yang dilakukan oleh bantuan enumerator. Uji statistic dengan menggunakan chi-square test. Hasil penelitian diketahui perilaku makan yang dikategorikan sering (tidak baik) pada kelompok kasus yaitu sebanyak 31 orang $(64,6 \%)$ dan pada kelompok kontrol sebanyak 17 orang (35,4\%). Responden pada kelompok kasus mayoritas bertekanan darah kategori tinggi sebanyak 25 orang $(71,4 \%)$ dan sebagiannya bertekanan darah normal sebanyak 10 orang $(28,6 \%)$. Disimpulkan ada pengaruh perilaku konsumsi makanan instan yang mengandung natrium terhadap tekanan darah pada penderita hipertensi. Diharapkan kepada penderita hipertensi agar mengurangi kebiasaan konsumsi makanan instant.
\end{abstract}

Kata Kunci : Perilaku Konsumsi, Makanan Instan, Hipertensi

\begin{abstract}
One of the main causes that make high blood pressure is to consume foods that contain a lot of sodium so that our bodies accommodate excessive blood is needed and fluid retention. Particularly in Indonesia, the consumer society and always want practical, but do not ever want her health care. This research is a descriptive analytic by using case-control design, a random sample as many as 35 cases and 35 controls. The data includes the data characteristics of the samples taken, instant food consumption and blood pressure in a sample with a blood pressure cuff that is done by the help of enumerators. Statistical tests using the chi-square test. Result is eating behavior often categorized (not both) in the case of as many as 31 people (64.6\%) and in the control group were 17 men (35.4\%). Majority of respondents in the group of cases of high blood pressure categories as many as 25 people (71.4\%) and some normal blood pressure by 10 people (28.6\%). Conclusion there is an effect of instant food consumption behavior containing sodium on blood pressure in patients with hypertension.
\end{abstract}

Key words : Instant Food Consumption and Hypertension 